\title{
ANALYSIS AND RESEARCH ON THE KEY FACTORS OF SPORTS IN MAINTAINING HUMAN HEALTH
}

\author{
ANÁLISE E PESQUISA SOBRE OS FATORES-CHAVE DO ESPORTE NA MANUTENÇÃODA \\ SAÚDE HUMANA
}

ANÁLISIS E INVESTIGACIÓN SOBRE LOS FACTORES CLAVE DEL DEPORTE PARA MANTENER LA

SALUD HUMANA

\section{Lina Sun' (iD) \\ (Physical Education Professional) Mingzhi Li ${ }^{1}$ D \\ (Physical Education Professional) \\ 1. Department of Sports, North China Institute of Science and Technology, Hebei, China.}

\section{Correspondence:}

Department of Sports, North China Institute of Science and Technology, Hebei 065201, China. sunlina@ncist.edu.cn

\begin{abstract}
Introduction: The research on the promotion of physical fitness of the human body by exercise has also attracted widespread attention in sports and rehabilitation medicine. Object: This article uses ultrasound to study the bone density health of the human body, thereby establishing the relationship between sports and bone density health. We hope to use the research results of this article to improve people's awareness of sports health. Method: We used ultrasound to test the bone mineral density of two groups of students (exercise group and non-exercise group) to explore the relationship between different sports items and the students' bone mineral density. Results: There is a significant difference in bone density between the two groups of students. There is no gender difference in bone density. Conclusion: Students need to strengthen physical exercise in the growth and development stage to improve bone density. Level of evidence Il; Therapeutic studies - investigation of treatment results.
\end{abstract}

Keywords: Sports; Bone Density; Bone Health; Middle Aged; Aged.

\section{RESUMO}

Introdução: A pesquisa sobre a promoção da aptidão física do corpo humano por meio do exercício também tem atraído atenção generalizada na medicina esportiva e de reabilitação. Objeto: este artigo usa o ultrassom para estudar a saúde da densidade óssea do corpo humano, estabelecendo assim a relação entre esportes e saúde da densidade óssea. Esperamos usar os resultados da pesquisa deste artigo para aumentar a conscientização das pessoas sobre a saúde no esporte. Método: Usamos ultrassom para testar a densidade mineral óssea de dois grupos de alunos (grupo de exercícios e grupo de não exercícios) para explorar a relação entre diferentes itens esportivos e a densidade mineral óssea dos alunos. Resultados: Existe uma diferença significativa na densidade óssea entre os dois grupos de alunos. Não há diferença de gênero na densidade óssea. Conclusão: Os alunos precisam fortalecer os exercícios físicos na fase de crescimento e desenvolvimento para melhorar a densidade óssea. Nível de evidência ll; Estudos terapêuticos - investigação dos resultados do tratamento.

Descritores: Esportes; Densidade Óssea; Saúde Óssea; Pessoa de Meia-Idade; Idoso.

\section{RESUMEN}

Introducción: La investigación sobre la promoción de la aptitud física del cuerpo humano mediante el ejercicio también ha atraído una amplia atención en la medicina deportiva y de rehabilitación. Objeto: Este artículo utiliza la ecografía para estudiar la salud de la densidad ósea del cuerpo humano, estableciendo así la relación entre el deporte y la salud de la densidad ósea. Esperamos utilizar los resultados de la investigación de este artículo para mejorar la conciencia de las personas sobre la salud deportiva. Método: Utilizamos ultrasonido para probar la densidad mineral ósea de dos grupos de estudiantes (grupo de ejercicio y grupo sin ejercicio) para explorar la relación entre diferentes artículos deportivos y la densidad mineral ósea de los estudiantes. Resultados: Existe una diferencia significativa en la densidad ósea entre los dos grupos de estudiantes. No hay diferencia de género en la densidad ósea. Conclusión: Los estudiantes necesitan fortalecer el ejercicio físico en la etapa de crecimiento y desarrollo para mejorar la densidad ósea. Nivel de evidencia ll; Estudios terapéuticos: investigación de los resultados del tratamiento.

Descriptores: Deportes; Densidad Ósea; La Salud Ósea; Personas de Mediana Edad; Anciano. 


\section{INTRODUCTION}

The physical health of college students is related to their development and the present and future of Chinese modernization, and bone health is an essential guarantee for physical health. 'Therefore, the study of sports in promoting the bone health of college students has also attracted widespread attention in fields such as sports and rehabilitation medicine. Bone density is an essential indicator of bone quality, reflecting the degree of osteoporosis and an essential basis for predicting fracture risk. ${ }^{2}$

This study uses an ultrasound bone density meter to measure the bone mineral density of college students. Based on reflecting the essential condition of college students' bone mineral density, this study explores the influence of gender, physical exercise and different sports on the calcaneal bone density of college students, with a view to the research results.

\section{METHOD}

\section{General information}

In this study, 78 social sports majors (regular exercise group) and 50 other non-sports majors (non-regular exercise group) were the research objects. Through the questionnaire survey, congenital bone diseases, diabetes, hyperthyroidism and other chronic diseases that affect bone metabolism were excluded.

\section{Technical route}

We adopted a two-factor (gender and exercise group) inter-group controlled experimental design. The dependent variables are the T value, $Z$ value and bone mass index (BQI) that reflect bone density.

\section{METHOD}

\section{Bone mineral density determination method and the mea- ning of related indicators}

We use the American GE Achilles Insight ultrasonic bone densitometer (the accuracy: bone mass index (BQI) less than $2 \%$, velocity change (SOS) less than $0.2 \%$, broadband ultrasonic attenuation (BUA) less than $1.4 \%$, and the test is tested for the part of the left heel bone, the relative value of bone density, T value, Z value and bone mass index (BQI) were obtained.

\section{Questionnaire survey and grouping method}

Questionnaires including essential information such as height, weight, history of related diseases that affect bone density, and exercise status were distributed to the subjects to screen the research subjects and obtain their basic information.

\section{Data statistical analysis method}

We export the test data in Excel format, and use SPSS16.0 data statistics software for statistical analysis and processing, and use "mean \pm standard deviation" $(\mathrm{M} \pm \mathrm{SD})$ to represent various inspection indicators. ${ }^{3}$ We mainly used a two-factor analysis of variance to investigate the influence of gender and exercise factors on bone mineral density-related indicators and used a t-test to analyze the differences between the regular exercise and the irregular exercise groups. We use $\mathrm{P}<0.05$ as the standard for the difference's significance and $\mathrm{P}<0.01$ as the standard for the very significant difference.

\section{Skeleton model based on Wolff's law}

(1) Quantitative analysis of the mechanical environment: at each instant, the bone is regarded as the same as the engineering material, and the finite element analysis method can be used to obtain the relevant quantities that characterize the mechanical environment at each point in the bone. (2) Use the bone model equation to describe the changes in bone structure and calculate the changes in the size, density and material properties of each point in the bone after a long enough time. (3) The first two steps repeatedly iterate until convergence: the end of the bone model so that a new bone structure that adapts to the new mechanical environment is obtained. The iterative formula used in the skeleton model:

$$
\rho_{j}(t+\Delta t)=\rho_{j}(t)+\Delta t \rho
$$

$\rho_{j}(t+\Delta t)$ is the density value of unit j at the time $t+\Delta t, \rho_{j}(t)$ is the density value of unit j at time $t, \Delta t$ is the time step in the iterative process. E $\rho$ is the apparent density change rate. ${ }^{4}$ The material model is isotropic, and the elastic modulus of the material parameter is calculated by the following formula

$$
E(x, t)=C_{\rho}(x, t)^{r}
$$

In the formula, $C, r$ is a constant, $\mathrm{E}$ is the modulus of elasticity, and $\rho$ is the apparent density. Poisson's ratio remains unchanged and is taken as a fixed value. Three-dimensional orthotropic materials have nine independent parameters: $E_{1}, E_{2}, E_{3}, v_{12}, v_{12}, v_{23}, v_{14}, G_{12}, G_{23}, G_{13}$ There are four two-dimensional orthotropic independent parameters: $E_{1}, E_{2}, v_{12}, G_{12}$. Basic equation: $\frac{d \rho(x, t)}{d t}=\tau\left(\sum_{i=1}^{N} f_{i}(x)\left(S_{i}-k\right)\right)$

$$
0<\rho(x) \leq \rho_{c b}
$$

Where $\tau$ is the time constant that controls the rate of reconstruction, $f_{i}(x)$ is the spatial influence function, $\mathrm{S}$ is the excitation, the strain energy density per unit mass is taken, $\mathrm{k}$ is the reference excitation, and $\rho_{c b}$ is the maximum bone density, usually taken as the density of compact bone. ${ }^{5}$

\section{RESULTS}

\section{The overall situation of college students' bone mineral density}

In this study, based on the diagnostic criteria recommended by the World Health Organization (WHO), combined with the actual situation of the bone mineral density of college students, the bone density ofT value> $1 S D,-1 S D<$ T value $<1 S D$, T value $<-1 S D$ was defined as "Higher" (means higher bone mass and good bone quality), "normal" (means average bone mass) and "low" (means low bone mass and bone loss). ${ }^{6}$ The specific conditions of college students'bone mineral density are shown in Table 1.

The proportion of people with higher bone density in the regular exercise group was significantly higher than that in the irregular exercise group, and only a minimal number of people had low bone mass; the irregular exercise group showed a higher proportion of standard and lower bone mass.

\section{Analysis of variance of bone mineral density-related indica- tors by gender and exercise group}

According to the results of the two-way analysis of variance, the difference in $\mathrm{BQ}$ I value between groups is very significant $(P=0.000<0.01$ ), and there is no gender difference; the difference in $T$ value between gender and group is very significant.

Table 1. Distribution of Bone Mineral Density Grade Evaluation of College Students.

\begin{tabular}{c|c|c|c|c|c}
\hline \multirow{2}{*}{ Gender } & \multirow{2}{*}{ Group } & \multirow{2}{*}{$\mathbf{n}$} & \multicolumn{3}{|c}{ Bone density evaluation/\% } \\
\cline { 4 - 6 } & & & Higher & Normal & Low \\
\hline \multirow{2}{*}{ Male } & Regular exercise group & 51 & 56.9 & 39.2 & 3.9 \\
\cline { 2 - 6 } & Irregular exercise group & 28 & 28.6 & 39.3 & 32.1 \\
\hline \multirow{2}{*}{ Female } & Regular exercise group & 27 & 74.1 & 25.9 & 0 \\
\cline { 2 - 6 } & Irregular exercise group & 22 & 45.5 & 45.5 & 9.1 \\
\hline
\end{tabular}




\section{Research on gender differences in bone mineral density of college students}

It can be seen from Table 2 and Table 3 that there are significant differences between men and women in various indicators of bone mineral density in the regular exercise group; there is no difference in the $\mathrm{BQ}$ I values of male and female students in the non-regular exercise group, only the $T$ and $Z$ values are different.

\section{The effect of exercise on bone density}

It can be seen from Table 4 that the differences in indicators between the boys'regular exercise group and the non-regular exercise group are very significant $(P<0.01)$, and there are also significant differences between the girls' groups $(P<0.05)$; this result suggests this kind of exercise the differences are more pronounced among boys.

\section{The impact of different sports on bone density}

The ball category covers tennis and badminton. Besides, other boys are classified into other sports groups.? (Table 5) The results showed that boys' bone mineral density indexes in the ball sports group were better than those in other sports groups $(P<0.05)$.

Table 2. Independent sample t-test results of each index of the bone mineral density of boys and girls in the regular exercise group.

\begin{tabular}{c|c|c|c|c|c}
\hline Index & gender & $\mathbf{n}$ & $\mathbf{M} \pm \mathbf{S D}$ & $\mathbf{t}$ & $\mathbf{P}$ \\
\hline \multirow{2}{*}{$\mathrm{BQl}$} & Boys & 51 & $121.29 \pm 15.21$ & \multirow{2}{*}{2.073} & \multirow{2}{*}{0.042} \\
\cline { 2 - 4 } & Schoolgirl & 27 & $113.56 \pm 16.56$ & & \\
\hline \multirow{2}{*}{ T value } & Boys & 51 & $1.427 \pm 1.26$ & \multirow{2}{*}{-2.299} & \multirow{2}{*}{0.024} \\
\cline { 2 - 4 } & Schoolgirl & 27 & $2.200 \pm 1.65$ & & \\
\hline \multirow{2}{*}{$Z$ value } & Boys & 51 & $1.514 \pm 1.26$ & \multirow{2}{*}{-2.103} & \multirow{2}{*}{0.039} \\
\cline { 2 - 4 } & Schoolgirl & 27 & $2.219 \pm 1.64$ & & \\
\hline
\end{tabular}

Table 3. Independent sample t-test results for bone mineral density of boys and girls in the irregular exercise group.

\begin{tabular}{|c|c|c|c|c|c|}
\hline Index & gender & $n$ & $\mathrm{M} \pm \mathrm{SD}$ & $t$ & $P$ \\
\hline \multirow{2}{*}{$\mathrm{BQ}$} & Boys & 28 & $104.36 \pm 21.42$ & \multirow{2}{*}{0.56} & \multirow{2}{*}{0.578} \\
\hline & Schoolgirl & 22 & $101.32 \pm 15.50$ & & \\
\hline \multirow{2}{*}{ T value } & Boys & 28 & $-0.004 \pm 1.80$ & \multirow{2}{*}{-2.032} & \multirow{2}{*}{0.048} \\
\hline & Schoolgirl & 22 & $0.977 \pm 1.55$ & & \\
\hline \multirow{2}{*}{$Z$ value } & Boys & 28 & $-0.007 \pm 1.79$ & \multirow{2}{*}{-2.06} & \multirow{2}{*}{0.045} \\
\hline & Schoolgirl & 22 & $0.986 \pm 1.55$ & & \\
\hline
\end{tabular}

Table 4. Independent sample t-test results of bone mineral density among boys in different sports groups.

\begin{tabular}{c|c|c|c|c|c}
\hline & Index sport group & $\mathbf{n}$ & $\mathbf{M} \pm$ SD & $\mathbf{t}$ & $\mathbf{P}$ \\
\hline \multirow{2}{*}{ Bone strength } & Regular exercise group & 51 & $121.29 \pm 15.21$ & \multirow{2}{*}{4.082} & \multirow{2}{*}{0.001} \\
\cline { 2 - 5 } & Irregular exercise group & 28 & $104.36 \pm 21.42$ & & \\
\hline \multirow{2}{*}{ T value } & Regular exercise group & 51 & $1.427 \pm 1.26$ & \multirow{2}{*}{3.736} & \multirow{2}{*}{0.001} \\
\cline { 2 - 5 } & Irregular exercise group & 28 & $-0.004 \pm 1.79$ & & \\
\hline \multirow{2}{*}{ Z value } & Regular exercise group & 51 & $1.514 \pm 1.26$ & \multirow{2}{*}{3.978} & \multirow{2}{*}{0.001} \\
\cline { 2 - 5 } & Irregular exercise group & 28 & $-0.007 \pm 1.79$ & & \\
\hline
\end{tabular}

Table 5. The t-test of various indexes of bone mineral density among boys of different sports.

\begin{tabular}{c|cc|c|c|c}
\hline Index & Sports & $\mathbf{n}$ & $\mathbf{M} \pm \mathbf{S D}$ & $\mathbf{t}$ & $\mathbf{P}$ \\
\hline \multirow{2}{*}{ Bone strength } & Ball group & 16 & $128.12 \pm 13.59$ & \multirow{2}{*}{2.25} & \multirow{2}{*}{50.029} \\
\cline { 2 - 6 } & Another sports group & 35 & $118.17 \pm 15.06$ & & \\
\hline \multirow{2}{*}{ T value } & Ball group & 16 & $1.994 \pm 1.12$ & \multirow{2}{*}{2.244} & \multirow{2}{*}{0.029} \\
\cline { 2 - 5 } & Another sports group & 35 & $1.169 \pm 1.25$ & & \\
\hline \multirow{2}{*}{ Z value } & Ball group & 16 & $2.100 \pm 1.16$ & \multirow{2}{*}{2.336} & \multirow{2}{*}{0.024} \\
\cline { 2 - 5 } & Another sports group & 35 & $1.246 \pm 1.23$ & & \\
\hline
\end{tabular}

\section{DISCUSSION}

The WHO lists osteoporosis as one of the three major diseases of middle-aged and older people. It is a common health problem faced by human beings and is being paid more and more attention by the medical profession. In the past, traditional concepts believed that osteoporosis was only a middle-aged or senile disease. Still, as people's lifestyle changes, more and more chronic diseases began to develop in the direction of youth.

In terms of gender differences in bone mineral density of college students: This study shows that there are significant differences in indicators between the boys'regular exercise group and the non-regular exercise group $(P<0.01)$, and there are also significant differences between the girls' groups $(P<0.05)$, the difference in $B Q$ land T values of female college students between the two groups was not significant, consistent with some results of this study.

The main reason for the gender difference in bone density is that the bones of men are more potent than women, and the cortical bone is thicker, and the bone content is higher. However, the gender difference in bone density of the human body shows different changes with age: bone mineral content increases with age from infant to adolescence and increase, and there is no noticeable gender difference. After puberty, the increase in bone mineral content is more pronounced in men than in women, while college students are at the end of puberty. ${ }^{8}$ Therefore, it is difficult to determine whether the gender difference in bone mineral density of college students in this particular period is significant.

The muscle strength of badminton and tennis players holding the clap hand is greater than that of the contralateral limb. The bone density of the humerus is also higher than that of the contralateral limb. Different sports have different stimulation of bone, which affects the construction and remodeling of bone. Research on the effects of different forms of exercise on the bone mineral density of adolescent women shows that the impact of impact exercise on bone mineral density is significantly higher than that of non-impact exercise. Some scholars have shown that different forms of exercise have different stimulating effects on bone, and therefore the impact on bone density also presents different characteristics. Among them, strength exercises and impact exercises are the most helpful for improving bone density.

\section{CONCLUSION}

This study shows that the bone mineral density of college students in the regular exercise group is better than that of the irregular exercise group. The bone density of the irregular exercise group is lower. In particular, boys should pay enough attention. Regular exercise male and female college students are significantly higher than the non-regular exercise group in the examined bone mineral density index, suggesting that regular participation in sports promotes the increase of human bone density and strengthens bone strength.

\section{ACKNOWLEDGMENTS}

People's Livelihood Research Project of Hebei Province Federation of Social Science Circles, Research on Physical Education of Improving Students'Sense of Acquisition from the Perspective of People Oriented, Project Label 201701936.

All authors declare no potential conflict of interest related to this article 
AUTHORS' CONTRIBUTIONS: Each author made significant individual contributions to this manuscript. Mingzhi Li selected the left heel bone mineral density of 78 regular exercise students and 50 irregular exercise students and analyzed and study the obtained bone strength index, T value, and Z value. Lina Sun focused on the results, and was a major contributor in writing the manuscript.

\section{REFERENCES}

1. Tsorlakis N, Grouios G, Tsorbatzoudis H, Hatzitaki V. Footedness related differences in femoral bone mineral density in elderly women with osteoporosis. Int J Neurosci. 2020;130(1):97-102.

2. Ghasemi S, Sadeghi H. What Effect Do Different Training Environments Have on Femoral Bone Density in Premenopausal Women? JAST. 2020 [cited 2021 Jun 9];4(2):83-92. Available from: http:// jast.uma.ac.ir/article_1033_22a01634c2a465f56f1f089b127e1c40.pdf

3. Qazi SL, Sirola J, Kröger H, Honkanen R, Isanejad M, Airaksinen O, et al. High postural sway is an independent risk factor for osteoporotic fractures but not for mortality in elderly women. J Bone Miner Res. 2019;34(5):817-24.

4. Jin N, Park S. The relationships between resistance training and bone mineral density of the elderly: A meta-analytic approach. International Journal of Applied Sports Sciences. 2019;31(2): 175-85.

5. Ricci C, Gervasi F, Havemann Nel L, Smuts CM, Kruger SH, Leitzmann MF. Substitution of sedentary time with light physical activity is related to increased bone density in U.S. women over 50 years old. An iso-temporal substitution analysis based on the National health and Nutrition Examination Survey. Eur J Sport Sci. 2019;19(10):1404-13.

6. Wang Z, Yao G, Tao X, Zhang J, Zhang T, Wu Z. Evaluation of bone mineral density and 25-(OH) vitamin $D$ levels in middle-aged and elderly women with recurrent benign paroxysmal positional vertigo. Acta Otolaryngol. 2020;140(2):89-93.

7. Hartley C, Folland JP, Kerslake R, Brooke-Wavell K. High-impact exercise increased femoral neck bone density with no adverse effects on imaging markers of knee osteoarthritis in postmenopausal women. J Bone Miner Res. 2020;35(1):53-63.

8. Madansingh $\mathrm{SI}$, Ngufor CG, Fortune E. Quality over quantity: skeletal loading intensity plays a key role in understanding the relationship between physical activity and bone density in postmenopausal women. Menopause. 2020;27(4):444-449. 